\title{
УДК: 343.125.5
}

DOI: https://doi.org/10.32366/2523-4269-2021-\%6-3-158-168

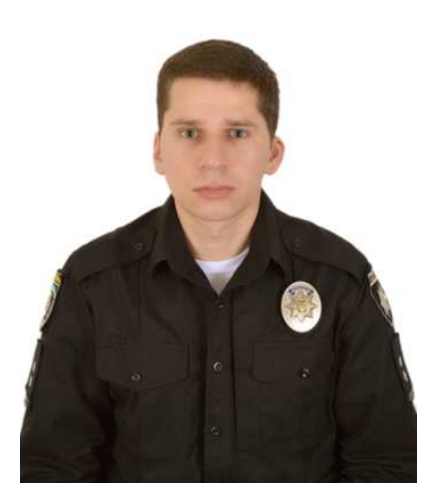

\author{
Потоцький Мирослав Михайлович, \\ ад'юнкт \\ (Донечъкий державний університет \\ внутрішніх справ, м. Кривий Ріг) \\ ORCID: https://orcid.org/0000-0002-2979-9114
}

\section{ПОНЯТТЯ ЕФЕКТИВНОСТІ ЗАТРИМАННЯ ОСОБИ У КРИМІНАЛЬНОМУ ПРОВАДЖЕННІ}

Статтю присвячено дослідженню поняття ефбективності затримання особи у криміналъному провадженні. Виділено три ознаки поняття еббективності кримінального проиесуального затримання: оперативне досягнення мети; легальність на підставі якісного закону; короткостроковістъ обмеження права на свободу. На основі дослідження вказаних ознак сбормулъовано поняття ебективності кримінального прочесуального затримання. Ебективність криміналъного прочесуалъного затримання ие здатність затримання в легальний спосіб, шо регламентований якісним кримінальним прочесуалъним законом, шляхом короткострокового обмеження права на свободу, здатність оперативно досягнути мети иодо забезпечення належної поведінки підозрюваного та інфбормачійного забезпечення початкового етапу досудового кримінального провадження.
Ключові слова:
оперативність; правопорушення.
еобективністъ; легальність;
затримання; короткостроковістъ;

Постановка проблеми. Кримінальне процесуальне затримання $\epsilon$ важливим інструментом кримінальної процесуальної діяльності сторони обвинувачення. Саме ефективність затримання характеризує останнє з точки зору дієвості, якості та корисності для кримінального провадження. Визначенню поняття ефективності кримінального процесуального затримання в науковій літературі приділено недостатньо уваги. 3'ясування цього поняття $є$ початковим етапом у дослідженні шляхів підвищення ефективності такого заходу примусу. Актуальність дослідження поняття ефективності кримінального процесуального затримання посилюється i тим, що досягнення однозначного розуміння ефективності затримання може слугувати надійним підгрунтям для розробки та вдосконалення ефективності кримінального процесуального затримання.

Аналіз останніх досліджень та публікацій. Окремі проблемні питання ефективності затримання особи у кримінальному провадженні вивчали такі науковці, як В. С. Зеленецький, Л. М. Лобойко, Т. О. Лоскутов, С. І. Макаренко, С. М. Смоков, I. В. Тарасова, В. В. Тіщенко, О. В. Шульга та інші. Незважаючи на достатню кількість напрацювань щодо затримання особи у кримінальному провадженні, на сьогодні немає єдиного розуміння поняття ефективності затримання в науковій літературі.

Метою статті $\epsilon$ виокремлення та аналіз ознак ефективності кримінального процесуального затримання, на основі вказаних ознак формулювання поняття ефективності затримання особи у кримінальному провадженні. 
Виклад основного матеріалу. Поняття «ефективність» доцільно розглядати як систему різних елементів, які визначають не тільки фактичну ефективність, а й характеризують останню щодо вимог обгрунтованості, доцільності, корисності, економності [1, с. 111]. Фактичну ефективність розуміємо як досягнення мети затримання особи. Однак не всі кримінальні процесуальні затримання, унаслідок яких вдалося досягнути мети відповідно до етапу розслідування, можна вважати однаково ефективними. Важливим аспектом $є$ набір засобів і способів досягнення такої мети та затрачений проміжок часу.

Для з'ясування рівня ефективності сучасного кримінального процесуального затримання та розробки рекомендацій щодо його підвищення насамперед необхідно розтлумачити поняття ефективності кримінального процесуального затримання, тобто визначити критерії оцінки ефективності такої процесуальної дії.

На підставі аналізу наукової літератури та чинного законодавства виокремлюємо три ознаки ефективності затримання особи у кримінальному провадженні.

1. Оперативне досягнення мети.

Урахування такого критерію, як досягнення мети та визначення його як основного обумовлено тим, що співвідношення результатів діяльності та ії мети є визначальним у розумінні поняття ефективності будь-якого виду людської діяльності [2, с. 186]. Т. О. Лоскутов ефективною називає діяльність, під час якої були досягнуті попередньо заплановані результати (мета) [1, с. 109]. Якщо бажаного результату не досягнуто, то про ефективність діяльності не може бути й мови. У цьому разі вже неважливо, наскільки обгрунтовані та досконалі засоби були використані для його досягнення.

Функціональне призначення кримінального процесуального затримання було предметом наукового дослідження наших попередніх праць. Так, універсальними функціями затримання можна вважати: припинення кримінальних правопорушень; інформаційне забезпечення початкового етапу кримінальної процесуальної діяльності; забезпечення проведення першочергових процесуальних дій за участю затриманого; запобігання неналежної поведінки підозрюваного на первісному етапі розслідування; створення умов для вирішення питання про застосування або зміну запобіжного заходу [3, c. 200]. Універсальною метою кримінального процесуального затримання, на нашу думку, $\epsilon$ забезпечення належної поведінки підозрюваного та інформаційного забезпечення початкового етапу досудового кримінального провадження.

Затримання особи повністю втрачає свою ефективність у разі фактичного незатримання особи під час здійснення такої процесуальної дії. Тому належну поведінку «підозрюваного» гарантувати неможливо, а також ця ситуація не має ніякої корисної інформації для органів кримінального переслідування. На думку С. І. Макаренка, у разі втечі та переховування злочинця від органу досудового розслідування відкрите стосовно нього кримінальне провадження, по суті, втратить свою судову перспективу [4, с. 177].

Якщо йдеться про затримання особи відразу після вчинення правопорушення або безпосередньо / щойно після вчинення, критерій «оперативність» досягнення мети затримання відіграє вирішальну роль. Ефективним затримання можна назвати те, яке було здійснено оперативно, тобто 3 мінімальними втратами часу та засобів. Так, у підозрюваного залишається менше часу для того, щоб спотворити сліди правопорушення, позбутися речей, здобутих протиправним шляхом, зв'язатися зі співучасниками тощо. Під час здійснення оперативного затримання зв'язок між правопорушенням (місцем його вчинення) та злочинцем буде стійким і нерозривним, адже час та місце затримання, обстановка затримання можуть вказувати на додаткову доказову інформацію.

Якщо правопорушника затримано неоперативно, протягом значного проміжку часу 3 моменту вчинення правопорушення, викривальні докази, найімовірніше, вже будуть втрачені (особистий обшук навряд чи дасть результати). Під час оперативного досягнення мети затримання важливе місце займає i психологічний момент. Як зазначав 
€. I. Макаренко, грамотно сплановане затримання хабарника «на гарячому» $є$ одним із дієвих способів його викриття, оскільки дає можливість зафіксувати факт передачі та вилучення предмета хабаря. Факт затримання «на гарячому» чинить настільки разючий психологічний вплив на хабарника, що не залишає останньому іншого вибору, як зізнатися у скоєному [5, с. 130]. Такі затримання можна назвати найбільш ефективними. Отже, результативним можна вважати тільки те затримання, яке було здійснено оперативно.

Затримання можна назвати неефективним, коли мету, що стояла перед уповноваженою службовою особою, не було досягнуто в повному обсязі. Наприклад, у разі затримання хабарника «на гарячому» відбулася втрата коштів, які слугували головним джерелом доказової інформації. Так, неефективність затримання, імовірно, знайде прояв у недостатності доказів для здійснення повідомлення про підозру. Переважно під час затримання осіб на підставах, зазначених у пп. 1,2 ч. 1 ст. 208 Кримінального процесуального кодексу України (далі - КПК України), першочерговою метою є забезпечення належної поведінки підозрюваного, що виражається в конкретних діях, а саме в оперативному припиненні правопорушення. Фізичне захоплення правопорушника $є$ дієвим засобом припинення правопорушень, оскільки затриманий позбавляється фізичної можливості продовжувати правопорушення або вчинити нове. Якщо метою затримання є інформаційне забезпечення початкового етапу розслідування, то ефективність такого затримання залежить від багатьох факторів. Такими факторами можуть бути: місце та час затримання, результати особистого обшуку, бажання затриманого співпрацювати 3 державними органами, вчасність проведення експертиз тощо.

На практиці може трапитися ситуація, за якої особу правопорушника було затримано, тобто мету начебто досягнуто, але досягнуто неоперативно, i тому неефективно. Наприклад, під час учинення крадіжки злочинця було затримано через декілька годин, однак у процесі особистого обшуку предмет посягання виявлено не було та інформації щодо його знаходження не здобуто. Унаслідок неоперативного затримання відбулася втрата доказової інформації.

Затримання можна вважати ефективним за умови, коли в законний спосіб, протягом двадцяти чотирьох годин встановлено мінімальну причетність особи до вчинюваного правопорушення, що є достатнім для повідомлення про підозру. У свою чергу, логічним $\epsilon$ припущення, що кримінальне процесуальне затримання $\epsilon$ не менш ефективним і в разі, коли причетність затриманого до вчинюваного правопорушення не підтвердилася. Такий результат також можна назвати «позитивним» для сторони обвинувачення, оскільки, отримавши дані щодо непричетності умовного «підозрюваного», досудове розслідування все одно мало певний успіх. Цю думку поділяють В. С. Зеленецький та Л. М. Лобойко. Науковці стверджують, що непритягнення невинної особи до відповідальності є таким же цінним для суспільства, як і притягнення винних до відповідальності [2, с. 192].

Отже, ефективність кримінального процесуального затримання залежить від оперативності досягнення мети, яка, у свою чергу, залежить від конкретних обставин справи, етапу кримінального провадження та завдань, які ставить перед собою уповноважена службова особа.

2. Легальність на підставі якісного закону.

Усі принципи кримінального процесу впливають на ефективність досудового розслідування незалежно від того, чи прямо вони направлені на регулювання кримінальної процесуальної діяльності на стадії досудового розслідування [6, с. 109]. Законність є однією з ключових засад кримінального провадження. Слово «законний» та словосполучення «відповідно до процедури, установленої законом» за своєю суттю 
належать до національного законодавства та визначають зобов'язання забезпечувати дотримання матеріально-правових і процесуальних норм законодавства [7].

Нагальна необхідність запобігти злочинові чи його припинити обумовлює переважно правомірність здійснення затримання особи, що діє злочинно, тобто обумовлює «зняття» 3 неї за цих обставин особистої недоторканності [8, с. 115]. Коли йдеться про позбавлення свободи, надзвичайно важливою умовою $\epsilon$ забезпечення загального принципу юридичної визначеності. Умови обмеження права на свободу повинні бути чітко сформульовані та їх застосування повинно бути передбачуваним [9]. У рішеннях Європейського суду з прав людини (далі - ЄСПЛ) неодноразово розглядається поняття «якість закону». Словосполучення «згідно із законом» розуміють як умови, що склалися поза межами наявної правової підстави в національному законодавстві та вимагають доступності й передбачуваності правової підстави. Норма закону $\epsilon$ передбачуваною, якщо вона сформульована 3 достатньою чіткістю, що дає змогу кожному вивіряти свою поведінку. Словосполучення «згідно із законом» нерозривно пов'язано 3 вимогою якості закону, тобто вимогою дотримання принципу верховенства права [10].

Словосполучення «відповідно до закону» має два компоненти. По-перше, право повинно бути достатньо доступним. Тобто громадяни повинні мати можливість орієнтуватися в тому, які правові норми мають застосовуватися в конкретному випадку. По-друге, норма права повинна бути сформульована 3 достатнім ступенем точності, що дасть змогу погоджувати 3 нею свою поведінку та передбачати наслідки [11]. Для того, щоб національне законодавство відповідало вимогам якості, воно має забезпечувати відповідний рівень правового захисту від свавільного втручання держави у права, передбачені Конвенцією про захист прав людини і основоположних свобод (далі Конвенція). Закон повинен досить чітко регламентувати таке втручання та спосіб його здійснення [12].

Є. С. Осетрова та М. А. Грига на підставі аналізу рішень ССПЛ виокремили умови, за яких затримання вважається законним: 1) якщо затримання здійснюється в межах кримінального провадження та за наявності підозри у вчиненні злочину; 2) якщо затримання особи здійснюється в порядку, встановленому законом; 3) за наявності мети, яка полягає в допровадженні підозрюваного до суду [13, с. 88]. Поділяємо думку авторів щодо меж кримінального провадження, однак хотілося б наголосити на певних особливостях. Формально кримінальне провадження починається з моменту внесення відомостей до Єдиного реєстру досудових розслідувань (далі - СРДР). Проте затримання особи, яке було здійснено «на гарячому», як правило, відбувається до внесення відповідних відомостей до ЄРДР. У цьому разі все одно варто вважати, що таке затримання було проведено в рамках кримінального провадження, оскільки фактично 3 моменту затримання досудове розслідування вже почалося.

O. В. Шульга, крім указаних вище вимог законності затримання, виокремив: розпочате досудове розслідування; уповноваженість (компетентність) службової особи, яка здійснює затримання [14, с. 361]. Не можемо не звернути увагу на той факт, що в національному законодавстві не надано перелік службових осіб, уповноважених здійснювати кримінальне процесуальне затримання. Така правова невизначеність призводить до непередбачуваності закону, що, звісно, не свідчить про його якість. Здійснювати кримінальне процесуальне затримання повинні уповноважені службові особи, право на затримання яким надано спеціальним законом (наприклад, Закон України «Про Національну поліцію», Закон України «Про Службу безпеки України», Закон України «Про Національну гвардію України» та інші). Наявність у національному законодавстві конкретизованого переліку уповноважених службових осіб дало б змогу більш ефективно застосовувати кримінальне процесуальне затримання у кримінальному провадженні. 
Незаконне або неправомірне здійснення кримінального процесуального затримання може спричинити порушення права на свободу, та, як наслідок, - порушення інших прав і свобод людини під час кримінального судочинства [15, с. 244]. Поширеною є практика незареєстрованих (неофіційних) затримань, коли затримана особа перебуває під повним контролем правоохоронців, які збирають можливі докази іiі причетності до правопорушення без жодної реєстрації своїх дій та забезпечення процесуальних прав і гарантій «підозрюваної» особи. У разі незареєстрованого затримання момент затримання переноситься на більш пізній етап (якщо затримання взагалі буде зареєстровано). За цих обставин порушується право особи на захист, право на повідомлення інших осіб про затримання тощо [16, с. 2]. Відправною точкою в сучасній організації досудового розслідування досі є отримання від підозрюваної особи зізнання та інших відомостей обвинувального ухилу $[17$, с. 1]. ЄСПЛ у справі «Курт проти Туреччини» зауважує, що незареєстроване затримання грубо порушує вимоги статті 5 Конвенції. Суд указує, що відсутність даних про час та місце затримання, ім'я затриманої особи, підстав для затримання та даних про уповноважену службову особу, яка здійснила затримання варто вважати несумісними з метою статті 5 Конвенції [18].

У подальшому, після незареєстрованого затримання часто із використанням фізичного та психічного насильства, від затриманих осіб отримуються відомості щодо їх причетності до правопорушення, які згодом «легалізуються» у докази [16, с. 2]. У разі незареєстрованого затримання підвищується ризик свавілля, ризик порушення права на заборону катування, що, у свою чергу, порушує норму закону, а отже затримання перестає бути ефективним. Докази, здобуті під час такого затримання, будуть визнані судом недопустимими внаслідок здійснення неефективного затримання.

I. В. Тарасова зауважує, що «норма ст. 208 КПК України виписана так, що на практиці застосування іiї є обмеженим» [19, с. 111]. Авторка має на увазі ті обставини, що затримання на підставах, зазначених у пп. 1, 2 ч. 1 ст. 208 КПК України, застосовується 3 урахуванням вимог, які відповідають термінам «безпосередньо» та «щойно», крім певних виключень (пп. 3, 4 ч. 1, ч. 3 ст. 208 КПК України). Уповноважені службові особи позбавлені можливості здійснити затримання без ордера, якщо 3 моменту вчинення правопорушення минув значний проміжок часу (на практиці такий проміжок часу визначають досить по-різному). Отже, у разі затримання особи протягом значного проміжку часу затримання буде вважатися незаконним та, як наслідок, неефективним. У такому разі всі докази, здобуті під час затримання та які є похідними від затримання, викликають сумніви. Така недосконалість національного законодавства суттєво обмежує можливості сторони обвинувачення та загалом негативно впливає на ефективність досудового кримінального провадження.

Не покращує ефективність затримання і той факт, що правоохоронці мають право затримати особу за підозрою в учиненні злочину, за який передбачено покарання у вигляді позбавлення волі, або в окремих випадках за підозрою в учиненні кримінального проступку. Відповідно до Кримінального кодексу України кримінальним проступком $\epsilon$ діяння, за вчинення якого передбачене основне покарання у виді штрафу в розмірі не більше трьох тисяч неоподатковуваних мінімумів доходів громадян (далі - НМДГ) або інше покарання, не пов'язане з позбавленням волі [20]. Постає питання: як затримати особу за вчинення злочину, за який передбачено покарання понад трьох тисяч НМДГ і не передбачено в санкції позбавлення волі. У цій ситуації спостерігаємо непередбачуваність закону. Адже логічною є думка, що кримінальне процесуальне затримання «на гарячому» можна застосовувати службовими особами за вчинення будь-якого злочину, оскільки останне можна використовувати за вчинення будь-якого кримінального проступку, рівень якого, у свою чергу, за суспільною небезпекою є нижчим за злочин. Як стверджує Т. О. Лоскутов, поза предметом регулювання КПК України залишається можливість затримання особи за підозрою у скоєнні злочину, покарання за який не пов'язано 3 
санкцією позбавлення волі. Не можна вважати цей підхід законодавця досконалим, оскільки під час розслідування таких злочинів також необхідно забезпечувати належну поведінку підозрюваних осіб та оперативне встановлення обставин злочинного діяння [15, c. 245]. У зв'язку 3 невідповідністю вимозі «якість закону» окремих аспектів кримінального процесуального закону, іноді під час правозастосування краще не ризикувати й не затримувати потенційних порушників. 3 огляду на недосконалість закону в окремих випадках це буде більш ефективним.

Важливе значення для легальності затримання має дотримання процесуальної форми. Це є визначальним під час оцінки законності, обгрунтованості затримання та під час оцінки доказів. Однак навіть дотримання законної процедури не завжди буде свідчити про ефективність затримання. Відкритим проблемним питанням $є$ затримання та подальший процесуальний супровід осіб, анкетні дані яких не відомі. Законом не передбачено процедури поводження 3 такими особами (порядок виклику, застосування запобіжних заходів та взагалі прийняття остаточного рішення у справі).

Більш детальна регламентація в законодавстві згаданих вище проблемних аспектів повинна підвищити якість закону та, як наслідок, ефективність затримання особи у кримінальному провадженні.

3. Короткостроковість обмеження права на свободу.

Стаття 5 Конвенції гарантує основоположне право на свободу та особисту недоторканність. Це право $є$ найважливішим у «демократичному суспільстві» в розумінні Конвенції [9]. Будь-яка особа, позбавлена волі, утримується в офіційно визнаних місцях для затримання і відповідно до національного законодавства постає перед судовим органом незабаром після затримання [21]. У затриманої особи повинна бути можливість бути заслуханою в судовому органі негайно після затримання [22].

Стосовно кримінального процесуального затримання гарантії мають демонструвати найвищий рівень ефективності, оскільки такий захід примусу за своїм характером $\epsilon$ невідкладним та доволі поширеним засобом обмеження свободи у вітчизняній практиці [8, с. $115 ; 23$, с. 64].

Кожен, хто піддався кримінальному процесуальному затриманню, повинен бути в найкоротший строк доставлений до слідчого судді для вирішення питання про законність та обгрунтованість такого затримання та подальшого тримання. Протягом 72 годин 3 моменту затримання особі повинно бути вручено вмотивоване судове рішення про тримання під вартою [24; 25]. Встановлення законом обмеження права на свободу особи в годинах свідчить про значущість такого права та необхідність суворого дотримання процедури затримання.

72-годинний термін є гарантією не тільки затриманого, a i правосуддя. Цей конституційний строк примушує сторону обвинувачення працювати максимально швидко й ефективно у процесі пошуку доказів, що є корисним для правосуддя [8, с. 120]. Особа, яка затримана без ордера, не пізніше шістдесяти годин з моменту затримання повинна бути звільнена або доставлена до суду для розгляду клопотання про обрання стосовно неї запобіжного заходу [24]. Відповідно до КПК України, кожна процесуальна дія повинна бути виконана в розумні строки. Розумними вважаються строки, що є об'єктивно необхідними для виконання процесуальних дій [24]. Убачається, що строк у шістдесят годин є достатнім для з'ясування обставин на початковому етапі розслідування.

Звід принципів захисту всіх осіб, які піддаються затриманню чи ув'язненню будьяким чином, від 09.12.1988 р. вимагає проведення судового розгляду стосовно затриманої особи в розумні строки після іiі затримання або звільнення цієї особи до розгляду провадження в суді. Правосуддя має бути швидким. Тривала невиправдана затримка процесу практично рівнозначна відмові у правосудді [26]. Саме критерій «короткостроковості» $\epsilon$ визначальним у підвищенні ефективності затримання. О. В. Шульга зауважує, що, крім обмеження права на свободу й особисту 
недоторканність, застосування кримінального процесуального затримання обмежує також інші права особи, ставить під сумнів їі честь і репутацію, спричиняє моральні страждання у випадках його незаконного та необгрунтованого застосування [14, с. 358]. Отже, чим коротші строки затримання, тим меншими є обмеження прав людини та ризик свавілля.

Підтримуючи принцип «негайно постати перед суддею», С. М. Смоков зазначив, що суворим дотриманням цієї вимоги, крім іншого, процедурно підтверджується той факт, що підстави для затримання особи мали місце на момент затримання, а не були здобуті після затримання [8, с. 117]. Тобто чим довше тривав період кримінального процесуального затримання, тим більшими $є$ сумніви щодо достовірності доказів та інформації, наданих стороною обвинувачення.

Під час обмеження права на свободу та особисту недоторканність необхідно враховувати принцип доцільності та обгрунтованості. Тобто цілі, завдання та засоби їх досягнення повинні бути сумірними [6, с. 109]. Варто звернути увагу на принцип розумності строків. Строк у 72 години треба розцінювати як граничний, тобто максимально допустимий. Чим коротший термін обмеження права на свободу затриманого, тим прозорішими є дії правоохоронних органів, i, як наслідок, підвищується ефективність затримання, оскільки не ставиться під сумнів допустимість доказів. Цю тезу підтверджує i той факт, що чим пізніше після початку розслідування сторона обвинувачення звертається до суду з клопотанням про взяття під варту, тим суворішими стають вимоги до стандарту «розумна підозра», який використовується судом під час вирішення питання про ув'язнення [27, с. 147].

Зважаючи на те, що відповідно до національного законодавства кримінальне процесуальне затримання може відбуватися взагалі без судового контролю (особу повинно бути звільнено, якщо протягом двадцяти чотирьох годин з моменту затримання не було вручено повідомлення про підозру), строк такого затримання повинен бути взагалі мінімальним. Тому що в такому разі існує значний ризик свавілля.

Ефективність кримінального процесуального затримання враховує узгодженість інтересів держави та конкретної особи, баланс законних можливостей правоохоронних органів та ефективних механізмів захисту від свавілля.

Висновки. Три основні ознаки характеризують ефективність кримінального процесуального затримання: оперативне досягнення мети, легальність на підставі якісного закону, короткостроковість обмеження права на свободу.

На основі узагальнення виділених ознак можна сформулювати таке визначення поняття ефективності затримання особи у кримінальному провадженні: ефективність кримінального процесуального затримання - це здатність затримання в легальний спосіб, що регламентований якісним кримінальним процесуальним законом, шляхом короткострокового обмеження права на свободу, здатність оперативно досягнути мети щодо забезпечення належної поведінки підозрюваного та інформаційного забезпечення початкового етапу досудового кримінального провадження.

Перспективними напрямами подальших розвідок убачаємо дослідження шляхів підвищення ефективності кримінального процесуального затримання, впливу процесу правотворення на ефективність затримання.

\section{Список використаних джерел}

1. Лоскутов Т. О. Кримінальне переслідування, здійснюване слідчим : монографія. Дніпропетровськ : Ліра ЛТД, 2011. 164 с.

2. Зеленецький В. С., Лобойко Л. М. Критерії оцінки ефективності діяльності органів кримінального переслідування в Україні. Вісник Академї правових наук України. 2009. № 2. C. 185-196. URL: http://nbuv.gov.ua/UJRN/vapny_2009_2_20 (дата звернення: 18.08.2021).

3. Потоцький М. М. Функціональне призначення кримінального процесуального затримання. Правовий часопис Донбасу. 2020. № 2 (71). С. 197-203. 
4. Макаренко С. І. Правомірність затримання підозрюваного до відкриття кримінального провадження. Право $i$ суспільство. 2013. № 4. C. 174-181. URL: http://nbuv.gov.ua/UJRN/Pis_2013_4_32 (дата звернення: 18.08.2021).

5. Макаренко Є. І. Щодо сутності затримання підозрюваного за новим Кримінальним процесуальним кодексом України. Право і суспільство. 2013. № 3. С. 126-134.

6. Тіщенко В. В., Аленін Ю. П., Ващук О. П. Теоретичні та практичні проблеми забезпечення ефективності досудового провадження. Наукові праці Національного університету «Одеська юридична академія». 2015. Т. 17. С. 106-158.

7. Рішення ЄСПЛ у справі «Захаркін проти України» від 24.09.2010 p. URL: https://zakon.rada.gov.ua/laws/show/974_817\#Text (дата звернення: 18.08.2021).

8. Смоков С. М. Запобіжні заходи та кримінально-процесуальні гарантії їх застосування : навчальний посібник. Одеса : ОДУВС, 2015. 134 с.

9. Рішення ЄСПЛ у справі «Гарькавий проти України» від 18.05 .2010 p. URL: https://zakon.rada.gov.ua/laws/show/974_544\#Техt (дата звернення: 18.08.2021).

10. Рішення ЄСПЛ у справі № $277798 / 95$ «Аллан протии Швейцарії» від 16 лютого 2000 p. URL: http://eurocourt.in.ua/Article.asp?AIdx=308 (дата звернення: 16.08.2021).

11. Рішення ЄСПЛ у справі «“Санді Таймс” проти Сполученого Королівства» від 26 квітня 1979 p. URL: https://cedem.org.ua/library/sprava-sandi-tajms-proty-spoluchenogo-korolivstva2/ (дата звернення: 16.08.2021).

12. Case of Sanoma Uitgevers B.V. v. the Netherlands. The European Court of Human Rights. 14.09.2010. URL: https://hudoc.echr.coe.int/eng\#\{\%22itemid\%22:[\%22001-100448\%22]\} (дата звернення: 18.08.2021).

13. Осетрова Є. С., Грига М. А. Щодо мети та умов затримання уповноваженою службовою особою. Науковий вісник Міжнародного гуманітарного університету. Серія: Юриспруденція. 2018. Вип. 34. С. 86-89. URL: http://nbuv.gov.ua/UJRN/Nvmgu_jur_2018_34_21 (дата звернення: 18.08.2021).

14. Шульга О. В. Мета, умови та мотиви затримання уповноваженою службовою особою. Право і суспільство. 2014. № 6.1 (2). C. 357-362. URL: http://nbuv.gov.ua/UJRN/Pis_2014_6 (дата звернення: 16.08.2021).

15. Лоскутов Т. О. Окремі проблемні питання кримінального процесуального затримання. Кримінальна юстиція в Україні: реалії та перспективи: матеріали круглого столу (м. Львів, 11 червня 2021 року). Львів : Львівський державний університет внутрішніх справ, 2021. С. 244246.

16. Концепція змін в інституті затримання за підозрою у вчиненні кримінального правопорушення. Justtalk. URL: https://drive.google.com/file/d/1qzs4-spgaxdxr-daEnALKgWhraZgNm7/view?fbclid=lwAR1BHz3u-JYjmFnpR-f19xVvCvZSK0D_cY1CFM0KWG6YzhNmJVT-

zb2wvLc (дата звернення: 14.08.2021).

17. Як вивести із тіні затримання. Justtalk. URL: https://ecpl.com.ua/wpcontent/uploads/2019/06/DiscussionPaperForWeb.pdf (дата звернення: 14.08.2021).

18. Решение ЕСПЧ по делу «Курт против Турции» от 25.05.1998 г. [The decision of the ECHR in the case "Kurt against Turkey" of 25.05.1998]. URL: http://www.echr.ru/documents/doc/2461485/2461485.htm (дата звернення: 18.08.2021).

19. Тарасова I. В. Питання підвищення ефективності інституту затримання особи у кримінальному процесі України. Правничий вісник Університету «КРОК». 2017. Вип. 27. С. 108113. URL: http://nbuv.gov.ua/UJRN/Pvuk_2017_27_15 (дата звернення: 16.08.2021).

20. Кримінальний кодекс України : Закон України від 05.04.2001 p. № 2341-III. Вiдомості Верховної Ради Украӥни. URL: https://zakon.rada.gov.ua/laws/show/2341-14\#Техt (дата звернення: 15.08.2021).

21. Декларація 47/33 про захист усіх осіб від насильницького зникнення: Резолюція Генеральної Асамблеї ООН від 18 грудня 1992 року № 995_225. URL: https://zakon.rada.gov.ua/laws/show/995_225\#Tеxt (дата звернення: 18.08.2021).

22. Звід принципів захисту всіх осіб, які піддаються затриманню чи ув'язненню будь-яким чином від 09 грудня 1988 року. URL: https://zakon.rada.gov.ua/laws/show/995_206\#Теxt (дата звернення: 18.08.2021). 
23. Колос М. І. Роль суду у забезпеченні прав і свобод особи при затриманні і взятті під варту. Судовий контроль за дотриманням конституційних прав особи під час досудового розслідування. Київ : АДЕФ-Україна, 2005. С. 62-69.

24. Кримінальний процесуальний кодекс України : Закон України від 13.04.2012 p. № 4651VI. Відомості Верховної Ради України. URL: https://zakon.rada.gov.ua/laws/show/4651-17 (дата звернення: 12.08.2021).

25. Конституція України : Закон України від 28.06.1996 р. № 254к/96-ВР. Відомості Верховної Ради України. URL: https://zakon.rada.gov.ua/laws/show/254\%D0\%BA/96\%D0\%B2\%D1\%80 (дата звернення: 17.08.2021).

26. Постанова № 14 пленуму Вищого спеціалізованого суду України з розгляду цивільних і кримінальних справ від 19.12.2014 p. URL: https://zib.com.ua/ua/print/114155uzagalnennya_sudovoi_praktiki_schodo_trimannya_pid_vartoyu.html (дата звернення: 18.08.2021).

27. Лобойко Л.М., Банчук О.А. Кримінальний процес : навчальний посібник. Київ : Ваіте, 2014. $280 \mathrm{c}$.

\section{References}

1. Loskutov, T.O. (2011). Kryminalne peresliduvannia, zdiisniuvane slidchym: monohrafiia [Criminal prosecution carried out by the investigator : monograph] Dnipropetrovsk: Lira LTD. $164 \mathrm{~s}$. [in Ukrainian].

2. Zelenetskyi, V. S., Loboiko, L. M. (2009). Kryterii otsinky efektyvnosti diialnosti orhaniv kryminalnoho peresliduvannia v Ukraini. Visnyk Akademii pravovykh nauk Ukrainy [Criteria for assessing the effectiveness of criminal prosecution bodies in Ukraine. Bulletin of the Academy of Legal Sciences of Ukraine]. № 2. S. 185-196. URL: http://nbuv.gov.ua/UJRN/vapny_2009_2_20 (data zvernennia: 18.08.2021) [in Ukrainian].

3. Pototskyi, M. M. (2020). Funktsionalne pryznachennia kryminalnoho protsesualnoho zatrymannia. Pravovyi chasopys Donbasu [Functional purpose of criminal procedural detention. Law journal of Donbass]. № 2 (71). S. 197-203 [in Ukrainian].

4. Makarenko, Ye. I. (2013). Pravomirnist zatrymannia pidozriuvanoho do vidkryttia kryminalnoho provadzhennia. Pravo $i$ suspilstvo [Legality of detention of a suspect before the opening of criminal proceedings. Right and society]. № 4. S. 174-181. URL: http://nbuv.gov.ua/UJRN/Pis_2013_4_32 (data zvernennia: 18.08.2021) [in Ukrainian].

5. Makarenko, Ye. I. (2013). Shchodo sutnosti zatrymannia pidozriuvanoho za novym Kryminalnym protsesualnym kodeksom Ukrainy. Pravo $i$ suspilstvo [Regarding the essence of detention of a suspect under the new Criminal Procedure Code of Ukraine. Right and society]. № 3. S. 126-134 [in Ukrainian].

6. Tishchenko, V. V., Alenin, Yu. P., Vashchuk, O. P. (2015). Teoretychni ta praktychni problemy zabezpechennia efektyvnosti dosudovoho provadzhennia. Naukovi pratsi Natsionalnoho universytetu "Odeska yurydychna akademiia» [Theoretical and practical problems of ensuring the effectiveness of pre-trial proceedings. Scientific works of the National University "Odessa Law Academy»]. T. 17. S. 106-158 [in Ukrainian].

7. Rishennia YeSPL u spravi «Zakharkin proty Ukrainy» vid 24.09.2010 r. [The decision of the ECHR in the case of Zakharkin against Ukraine from February 24, 2010]. URL: https://zakon.rada.gov.ua/laws/show/974_817\#Text (data zvernennia: 18.08.2021) [in Ukrainian].

8. Smokov, S. M. (2015). Zapobizhni zakhody ta kryminalno-protsesualni harantii yikh zastosuvannia : navchalnyi posibnyk [Precautionary measures and criminal procedure guarantees of their application : tutorial]. Odesa : ODUVS. 134 s. [in Ukrainian].

9. Rishennia YeSPL u spravi «Harkavyi proty Ukrainy» vid 18.05.2010 r. [The decision of the ECHR in the case of «Garkivi versus Ukraine» of 18.05.2010] URL: https://zakon.rada.gov.ua/laws/show/974_544\#Text (data zvernennia: 18.08.2021) [in Ukrainian].

10. Rishennia YeSPL u spravi «Ällan protyy Shveitsarii» vid 16 liutoho 2000 r. [Decision in the case "Allan Alan Switzerland" from February 16, 2000]. URL: http://eurocourt.in.ua/Article.asp?AIdx=308 (data zvernennia: 16.08.2021) [in Ukrainian].

11. Rishennia YeSPL u spravi «"Sandi Taims” proty Spoluchenoho Korolivstva» vid 26 kvitnia 1979 r. [The decision in the case of Sandi Times against the United Kingdom of April 26, 1979]. URL: 
https://cedem.org.ua/library/sprava-sandi-tajms-proty-spoluchenogo-korolivstva-2/ (data zvernennia: 16.08.2021) [in Ukrainian].

12. Case of Sanoma Uitgevers B.V. v. the Netherlands. The European Court of Human Rights. 14.09.2010. URL: https://hudoc.echr.coe.int/eng\#\{\%22itemid\%22:[\%22001-100448\%22]\} (data zvernennia: 18.08.2021).

13. Osetrova, Ye. S., Hryha, M. A. (2018). Shchodo mety ta umov zatrymannia upovnovazhenoiu sluzhbovoiu osoboiu. Naukovyi visnyk Mizhnarodnoho humanitarnoho universytetu. Seriia: Yurysprudentsiia [Regarding the purpose and conditions of detention by an authorized official. Scientific Bulletin of the International Humanitarian University. Series: jurisprudence]. Vyp. 34. S. 86-89. URL: http://nbuv.gov.ua/UJRN/Nvmgu_jur_2018_34_21 (data zvernennia: 18.08.2021) [in Ukrainian].

14. Shulha, O. V. (2014). Meta, umovy ta motyvy zatrymannia upovnovazhenoiu sluzhbovoiu osoboiu. Pravo i suspilstvo [Purpose, conditions and motives of detention by an authorized official. Right and society]. № 6.1 (2). S. 357-362. URL: http://nbuv.gov.ua/UJRN/Pis_2014_6 (data zvernennia: 16.08.2021) [in Ukrainian].

15. Loskutov, T. O. (2021). Okremi problemni pytannia kryminalnoho protsesualnoho zatrymannia [Some problematic issues of criminal procedural detention]. Kryminalna yustytsiia $v$ Ukraini: realii ta perspektyvy: materialy kruhloho stolu (m. Lviv, 11 chervnia 2021 roku). Lviv : Lvivskyi derzhavnyi universytet vnutrishnikh sprav. S. 244-246 [in Ukrainian].

16. Kontseptsiia zmin $\mathrm{v}$ instytuti zatrymannia za pidozroiu u vchynenni kryminalnoho pravoporushennia. Justtalk. [The concept of change in the institution of detention. Justtalk] URL: https://drive.google.com/file/d/1 qzs4-spgaxdxr-daEnALKgWh-raZgNm7/view?fbclid=lwAR1BHz3u-

JYjmFnpR-f19xVvCvZSK0D_cY1CFM0KWG6YzhNmJVT-zb2wvLc (data zvernennia: 14.08.2021) [in Ukrainian].

17. Yak vyvesty iz tini zatrymannia. Justtalk [How to bring detention out of the shadows. Justtalk] URL: https://ecpl.com.ua/wp-content/uploads/2019/06/DiscussionPaperForWeb.pdf (data zvernennia: 14.08.2021) [in Ukrainian].

18. Reshenie ESPCH po delu «Kurt protiv Turcii» ot 25.05 .1998 g. [Kurt v. Turkey] URL: http://www.echr.ru/documents/doc/2461485/2461485.htm (data zvernennya: 18.08.2021) [in Russian].

19. Tarasova, I. V. (2017). Pytannia pidvyshchennia efektyvnosti instytutu zatrymannia osoby u kryminalnomu protsesi Ukrainy. Pravnychyi visnyk Universytetu «KROK» [The issue of increasing the efficiency of the institution of detention of a person in the criminal process of Ukraine. Legal Bulletin of the University «KROK»]. Vyp. 27. S. 108-113. URL: http://nbuv.gov.ua/UJRN/Pvuk_2017_27_15 (data zvernennia: 16.08.2021) [in Ukrainian].

20. Kryminalnyi kodeks Ukrainy: Zakon Ukrainy vid 05.04.2001 r. № 2341-III. Vidomosti Verkhovnoi Rady Ukrainy [Criminal Code of Ukraine : Law of Ukraine dated 05.04.2001 № 2341-III. Information on the Verkhovna Rada of Ukraine]. URL: https://zakon.rada.gov.ua/laws/show/234114\#Text (data zvernennia: 15.08.2021). [in Ukrainian].

21. Deklaratsiia $47 / 33$ pro zakhyst usikh osib vid nasylnytskoho znyknennia: Rezoliutsiia Heneralnoi Asamblei OON vid 18 hrudnia 1992 roku № 995_225 [Declaration 47/33 on the protection of all persons from violent disappearance: UN General Assembly: Resolution of December 18, 1992 № 995_225]. URL: https://zakon.rada.gov.ua/laws/show/995_225\#Text (data zvernennia: 18.08.2021) [in Ukrainian].

22. Zvid pryntsypiv zakhystu vsikh osib, yaki piddaiutsia zatrymanniu chy uviaznenniu budyakym chynom vid 09 hrudnia 1988 roku. [Code of principles for the protection of all persons subject to detention] URL: https://zakon.rada.gov.ua/laws/show/995_206\#Text (data zvernennia: 18.08.2021) [in Russian].

23. Kolos, M. I. (2005). Rol sudu u zabezpechenni prav i svobod osoby pry zatrymanni i vziatti pid vartu. Sudovyi kontrol za dotrymanniam konstytutsiinykh prav osoby pid chas dosudovoho rozsliduvannia [The role of the court in ensuring the rights and freedoms of the individual in detention and detention. Judicial control over observance of constitutional rights of a person during pre-trial investigation]. Kyiv : ADEF-Ukraina. S. 62-69 [in Ukrainian].

24. Kryminalnyi protsesualnyi kodeks Ukrainy: Zakon Ukrainy vid 13.04.2012 r. № 4651-VI. Vidomosti Verkhovnoi Rady Ukrainy [Criminal Procedural Code of Ukraine : Law of Ukraine dated 13.04.2012 № 4651-VI. Information on the Verkhovna Rada of Ukraine]. URL: https://zakon.rada.gov.ua/laws/show/4651-17 (data zvernennia: 12.08.2021) [in Ukrainian]. 
25. Konstytutsiia Ukrainy: Zakon Ukrainy vid 28.06.1996 r. № 254k/96-VR. Vidomosti Verkhovnoi Rady Ukrainy [Constitution of Ukraine : Law of Ukraine dated 28.06.1996 № 254к/96-BP. Information of the Verkhovna Rada of Ukraine]. URL: https://zakon.rada.gov.ua/laws/show/254\%D0\%BA/96-\%D0\%B2\%D1\%80 (data zvernennia: 17.08.2021) [in Ukrainian].

26. Postanova № 14 plenumu Vyshchoho spetsializovanoho sudu Ukrainy z rozghliadu tsyvilnykh i kryminalnykh sprav vid 19.12.2014 r. [Resolution of the Plenum of the Supreme Specialized Court of Ukraine for Civil and Criminal Cases]. URL: https://zib.com.ua/ua/print/114155uzagalnennya_sudovoi_praktiki_schodo_trimannya_pid_vartoyu.html (data zvernennia: 18.08.2021) [in Ukrainian].

27. Loboiko, L. M., Banchuk, O. A. (2014). Kryminalnyi protses : navchalnyi posibnyk [Criminal Process: tutorial]. Kyiv : Vaite. 280 s. [in Ukrainian].

\section{Pototskyi Myroslav,}

Postgraduate

(Donetsk State University of Internal Affairs, Kryvyi Rih)

ORCID: https://orcid.org/0000-0002-2979-9114

\section{THE CONCEPT OF EFFICIENCY OF DETENTION OF A PERSON IN CRIMINAL PROCEEDINGS}

The article focuses on the study of the concept of the effectiveness of detention of a person in criminal proceedings. It is emphasized that criminal procedural detention is an important tool of the criminal procedural activity of the prosecution. Not enough attention has been paid to the definition of the effectiveness of criminal procedural detention in the scientific literature. When posing the problem statement, it is noted that the study of the concept of the effectiveness of detention is the starting point in the study of ways to improve the effectiveness of such coercive measures. The relevance of the study of the concept of the effectiveness of criminal procedural detention is also enhanced by the fact that achieving a clear understanding of the effectiveness of detention can serve as a reliable basis for developing and improving the effectiveness of criminal procedural detention. The effectiveness of criminal procedural detention takes into account the balance of interests of the state and the individual, the balance of legal capabilities of law enforcement agencies and effective mechanisms for protection against arbitrariness. There are three signs of the effectiveness of criminal procedural detention: prompt achievement of the goal; legality on the basis of a qualitative law; short-term restriction of the right to liberty. During the presentation of the main material the procedural characteristic of each of them is given. We do not consider the selected criteria of efficiency of criminal procedural detention to be exclusive. The effectiveness of any criminal procedure institution is not a static phenomenon. It is dynamic and depends on the specific circumstances of the criminal proceedings. Based on the study of the above features, the concept of the effectiveness of criminal procedural detention is formulated. The effectiveness of criminal procedural detention is the ability to detain in a legal manner, regulated by a quality criminal procedural law, by short-term restriction of the right to freedom to promptly achieve the goal of ensuring proper conduct of the suspect and the information support of the initial stage of pre-trial criminal proceedings.

Key words: efficiency; detention; efficiency; legality; short-term; crime.

Надіслано до редколегії 19.08.2021 Рекомендовано до публікації 25.08.2021 